\title{
Serinicoccus profundi sp. nov., an actinomycete isolated from deep-sea sediment, and emended description of the genus Serinicoccus
}

Correspondence
Jun Xu
xu.junn@gmail.com

\author{
Jing Xiao, ${ }^{1,2}$ Yingxue Luo, ${ }^{1}$ Shujie $X_{i e}{ }^{1}$ and Jun $X u^{1,3}$ \\ ${ }^{1}$ Key Laboratory of Marine Biogenetic Resources, The Third Institute of Oceanography SOA, \\ Xiamen, Fujian 361005, PR China \\ ${ }^{2}$ Division of Integrative Environmental Sciences, Graduate School of Life and Environmental \\ Sciences, University of Tsukuba, Tsukuba, Ibaraki 305-8572, Japan \\ ${ }^{3}$ School of Life Sciences \& Biotechnology, Shanghai Jiao Tong University, Shanghai 200240, PR \\ China
}

\begin{abstract}
A Gram-reaction-positive bacterial strain of the genus Serinicoccus, designated MCCC $1 \mathrm{~A} 05965^{\top}$, was isolated from a deep-sea $(5368 \mathrm{~m})$ sediment of the Indian Ocean. Comparison of $16 \mathrm{~S}$ rRNA gene sequences revealed that the isolate shared $97.6 \%$ sequence similarity with Serinicoccus marinus $\mathrm{JC} 1078^{\top}$, the type strain of the only described species of the genus Serinicoccus. The DNA-DNA relatedness between these two strains was $46.2 \%$ (standard deviation $1.86 \%$ ). The cell wall contained alanine, glycine, serine, L-ornithine and glutamic acid, which corresponds to the description of the genus Serinicoccus. The acyl type of the glycan chain of the peptidoglycan was glycolyl. Other characteristics of strain MCCC $1 \mathrm{A05965^{ \top }}$ were consistent with those of the genus Serinicoccus. Cells were coccoid, moderately halophilic, oxidase-negative, catalase-positive and non-spore-forming. The major menaquinone was MK-8 $\left(\mathrm{H}_{4}\right)$. The predominant cellular fatty acids were iso- $\mathrm{C}_{15: 0}(34.7 \%)$ and iso- $\mathrm{C}_{16: 0}$ $(17.0 \%)$. The polar lipids were phosphatidylglycerol, diphosphatidylglycerol, phosphatidylcholine, phosphatidylinositol and an unknown glycolipid. The DNA G+C content was $72 \mathrm{~mol} \%$. Strain MCCC $1 \mathrm{A05965}^{\top}\left(=0714 \mathrm{~S} 6-1^{\top}=\mathrm{DSM} 21363^{\top}=\right.$ CGMCC $\left.4.5582^{\top}\right)$ is assigned as the type strain of a novel species, for which the name Serinicoccus profundi sp. nov. is proposed.
\end{abstract}

The genus Serinicoccus (family Intrasporangiaceae, suborder Micrococcineae) was proposed by Yi et al. (2004). The genus contains Gram-positive, strictly aerobic, moderately halophilic, oxidase-negative, catalase-positive, non-spore-forming, coccoid bacteria that have L-ornithine and L-serine as the diagnostic amino acids in the peptidoglycan (Yi et al., 2004). Serinicoccus marinus is the only described species in the genus. A search of GenBank/EMBL/DDBJ for Serinicoccus 16S rRNA gene sequences revealed five sequences: $S$. marinus $\mathrm{JC}_{1078}^{\mathrm{T}}$ (Yi et al., 2004) and Serinicoccus sp. CNJ927 (Gontang et al., 2007), JL1109 (accession no. DQ985074), JL1131 (DQ985072) and JL1097 (DQ985058), all of which were isolated from marine habitats.

Strain MCCC $1 \mathrm{~A} 05965^{\mathrm{T}}$ was isolated from deep-sea $(5368 \mathrm{~m})$ sediment of the Indian Ocean $\left(12^{\circ} 55.24^{\prime} \mathrm{S}\right.$ $76^{\circ} 09.03^{\prime}$ E) using the standard dilution-plating tech-

The GenBank/EMBL/DDBJ accession number for the 16S rRNA gene sequence of strain MCCC 1 A05965 ${ }^{\top}\left(=0714\right.$ S6- $\left.1^{\top}\right)$ is EU603762.

A supplementary table is available with the online version of this paper. nique on oligotrophic medium (seawater, $2.0 \%$ agar). The isolate was routinely cultured on modified ZoBell $2216 \mathrm{E}$ agar (ZBA; $0.5 \%$ tryptone, $0.1 \%$ yeast extract, $3.4 \%$ sodium chloride and $1.8 \%$ agar) at $30{ }^{\circ} \mathrm{C}$ and maintained as glycerol suspensions $\left(20 \%\right.$, v/v) at $-80{ }^{\circ} \mathrm{C}$. Biomass for chemical and molecular analyses was prepared from cells cultured in modified ZoBell $2216 \mathrm{E}$ broth $(\mathrm{ZBB})$ at $28{ }^{\circ} \mathrm{C}$ for 3 days in a rotary shaker and harvested by centrifugation.

The 16S rRNA gene was amplified and sequenced from a single colony using universal primers and conditions as described by Chun \& Goodfellow (1995). The almostcomplete 16S rRNA gene sequence (1490 nt) of strain MCCC $1 \mathrm{~A} 05965^{\mathrm{T}}$ was compared with sequences in the GenBank and EzTaxon databases using BLAST (Altschul et al., 1997; Chun et al., 2007) and aligned with sequences of representative taxa in GenBank using CLUSTAL x (Thompson et al., 1997). A phylogenetic tree was constructed using the maximum-parsimony and neighbour-joining methods in MEGA version 3.1 (Kumar et al., 2004; Saitou \& Nei, 1987). 
The tree topology was evaluated by bootstrap analysis (Felsenstein, 1985) with 1000 replications (Fig. 1). The closest relative of strain MCCC $1 \mathrm{~A} 05965^{\mathrm{T}}$ was S. marinus $\mathrm{JC} 1078^{\mathrm{T}}$ (97.6\% 16S rRNA gene sequence similarity).

Cell motility was examined on ZBA at $30{ }^{\circ} \mathrm{C}$ and cell morphology was observed by electron and transmission electron microscopy after cultivation for 3 days. Growth at $5-40{ }^{\circ} \mathrm{C}$ (at intervals of $5{ }^{\circ} \mathrm{C}$ ), at $\mathrm{pH} 4-12$ (at intervals of 1 $\mathrm{pH}$ unit) and with $0-15 \%(\mathrm{w} / \mathrm{v}) \mathrm{NaCl}$ (at intervals of $1 \%$ ) was determined using ZBA as the basal medium. The Gram reaction was assessed by using the $\mathrm{KOH}$ lysis test (Czerny, 1978). Physiological and biochemical tests were performed according to standard procedures (Shirling \& Gottlieb, 1966). Hydrolysis of Tween 80 was tested using ZBA as the basal medium. DNase test agar and triple-sugar iron agar (Hangzhou Microbial Reagent Co.) were used to test for DNase and production of $\mathrm{H}_{2} \mathrm{~S}$. Biochemical tests, such as nitrate reduction, indole production, acid production from glucose, arginine dihydrolase, urease, $\beta$-glucosidase, gelatin hydrolysis, $\beta$-galactosidase and some carbohydrate assimilation tests, were performed using the API 20NE system (bioMérieux). Enzyme activities were determined using the API ZYM system (bioMérieux). Carbon source assimilation was tested using the GP2 MicroPlate system (Biolog), according to the manufacturer's instructions. Resistance to various antibiotics was determined with antimicrobial susceptibility discs (Oxoid).

Strain MCCC $1 \mathrm{~A} 05965^{\mathrm{T}}$ was a Gram-reaction-positive, aerobic, moderately halophilic bacterium. Cells were nonmotile cocci. The results of biochemical and physiological tests are summarized in the species description.

Triglycerides were extracted and saponified and the resultant fatty acids were esterified as described by Sasser (1990) and determined by using the Microbial Identification System (MIDI) and Sherlock MIS Software. The cellular fatty acids were $\mathrm{C}_{14: 0}$, iso- $\mathrm{C}_{15: 0}$, anteiso- $\mathrm{C}_{15: 0}$, iso$\mathrm{C}_{16: 0}, \mathrm{C}_{16: 0}$, anteiso- $\mathrm{C}_{17: 1} \omega 9 c$, iso- $\mathrm{C}_{17: 1} \omega 9 c$, iso- $\mathrm{C}_{17: 0}$, anteiso- $\mathrm{C}_{17: 0}, \quad \mathrm{C}_{17: 1} \omega 8 c, \mathrm{C}_{17: 1} \omega 6 c$ and $\mathrm{C}_{17: 0}$. Minor differences were found between the fatty acid patterns of strain MCCC $1 \mathrm{~A} 05965^{\mathrm{T}}$ and S. marinus $\mathrm{JC} 1078^{\mathrm{T}}$ (Supplementary Table S1, available in IJSEM Online). Phospholipid analysis was carried out as described by Komagata \& Suzuki (1987). The polar lipid pattern consisted of phosphatidylglycerol, diphosphatidylglycerol, phosphatidylinositol, phosphatidylcholine and an unidentified glycolipid. Genomic DNA of strain MCCC $1 \mathrm{~A} 05965^{\mathrm{T}}$ was extracted as described by Weisburg et al. (1991) and digested and dephosphorylated before determination of the base composition by HPLC analysis (Tamaoka \& Komagata, 1984). The molar DNA G $+\mathrm{C}$ content was calculated according to Mesbah et al. (1989) and found to be $72 \mathrm{~mol} \%$. Menaquinones were extracted by the method of Collins et al. (1977) and analysed by HPLC (Kroppenstedt, 1985). The major menaquinone of strain MCCC $1 \mathrm{~A} 05965^{\mathrm{T}}$ was MK-8 $\left(\mathrm{H}_{4}\right)$. DNA-DNA hybridization between strain MCCC $1 \mathrm{~A} 05965^{\mathrm{T}}$ and S. marinus DSM $15273^{\mathrm{T}}$ was performed using the DIG High Prime DNA labelling and detection starter kit II (Roche), according to the manufacturer's directions and $\mathrm{Xu}$ et al. (2009). DNADNA relatedness between strain MCCC $1 \mathrm{~A} 05965^{\mathrm{T}}$ and $S$. marinus DSM $15273^{\mathrm{T}}$ was $46.2 \%$ (SD $1.86 \%$ ).

Analysis of the peptidoglycan structure was performed by the Identification Service of the DSMZ, Braunschweig, Germany, as described by Schleifer (1985) and Schleifer \& Kandler (1972), using TLC on cellulose instead of paper. Quantitative analysis of amino acids was carried out by GC and GC/MS according to MacKenzie (1987). The acyl type of the peptidoglycan was determined by using the method of Uchida et al. (1999). The total hydrolysate of the peptidoglycan of strain MCCC $1 \mathrm{~A} 05965^{\mathrm{T}}$ contained the amino acids alanine, glycine, serine, L-ornithine and

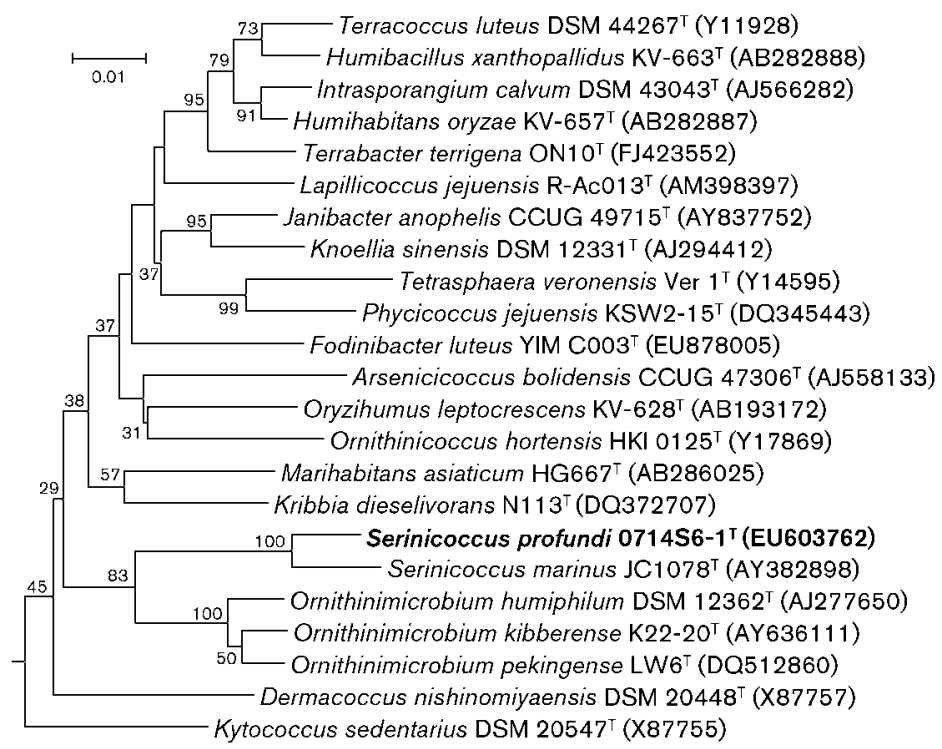

Fig. 1. Neighbour-joining tree showing the phylogenetic positions of strain $0714 \mathrm{~S} 6-1^{\top}$ $\left(=\right.$ MCCC $1{\mathrm{~A} 05965^{\mathrm{T}}})$ and representatives of related taxa, based on nearly complete $16 \mathrm{~S}$ rRNA gene sequences. Bootstrap values based on 1000 replications are shown at branch nodes. The sequence of Brevibacterium iodinum NCDO $613^{\top}$ was used as an outgroup (GenBank accession no. X76567; not shown). Bar, 0.01 substitutions per nucleotide position. 
glutamic acid. The identity of the amino acids was confirmed by electron impact MS (320-MS Quadrupole GC/MS; Varian). Quantitative analysis showed that alanine, glycine, serine, ornithine and glutamic acid were present in the ratio $1.5: 1.6: 0.7: 1.0: 2.0$ in strain MCCC $1 \mathrm{~A} 05965^{\mathrm{T}}$, which was a slightly different ratio from that observed in this study in S. marinus DSM $15273^{\mathrm{T}}$ $(2.2: 2.4: 0.9: 1.0: 3.1)$. Partial hydrolysis $\left(100{ }^{\circ} \mathrm{C}, 4 \mathrm{M}\right.$ $\mathrm{HCl}, 45 \mathrm{~min}$ ) produced the peptide L-Ala-D-Glu and glycine- and/or serine-containing peptides that could not be identified. Dinitrophenylation resulted in dinitrophenylated serine (ether extract) and ornithine (butanol extract), which suggests that serine represents the $\mathrm{N}$ terminus of the interpeptide bridge, as in S. marinus JC1078 ${ }^{\mathrm{T}}$. Strain MCCC $1 \mathrm{~A} 05965^{\mathrm{T}}$ showed the same peptidoglycan type as $S$. marinus $\mathrm{JC} 107 \mathrm{8}^{\mathrm{T}}$, which is a novel variation of peptidoglycan type A4 $\beta$. In contrast to $S$. marinus $\mathrm{JC} 1078^{\mathrm{T}}$, the acyl type of the peptidoglycan of strain MCCC $1 \mathrm{~A} 05965^{\mathrm{T}}$ was glycolyl.

The morphological traits, DNA G+C content, major menaquinone and occurrence of serine in the peptidoglycan of strain MCCC $1 \mathrm{~A} 05965^{\mathrm{T}}$ corresponded with the characteristics of the genus Serinicoccus. However, strain MCCC $1 \mathrm{~A} 05965^{\mathrm{T}}$ can be differentiated from S. marinus DSM $15273^{\mathrm{T}}$. The polar lipid profile of S. marinus DSM $15273^{\mathrm{T}}$ does not contain phosphatidylcholine. The carbon assimilation (Biolog GP2) and antibiotic susceptibility patterns of the two strains were different (Table 1). Strain MCCC $1 \mathrm{~A} 05965^{\mathrm{T}}$ was resistant to all of the $\beta$-lactam antibiotics tested, while S. marinus DSM $15273^{\mathrm{T}}$ was sensitive to those antibiotics. Strain MCCC 1A05965 ${ }^{\mathrm{T}}$ produced alkaline phosphatase while S. marinus DSM $15273^{\mathrm{T}}$ did not (API ZYM). The acyl type of the glycan chain of the peptidoglycan was different in strain MCCC $1 \mathrm{~A} 05965^{\mathrm{T}}$ and S. marinus DSM $15273^{\mathrm{T}}$. Based on the chemotaxonomic and physiological differences and DNADNA relatedness, it is proposed that strain MCCC $1 \mathrm{~A} 05965^{\mathrm{T}}$ represents a novel species of the genus Serinicoccus, for which we propose the name Serinicoccus profundi sp. nov.

\section{Emended description of the genus Serinicoccus Yi et al. 2004}

The genus description is as given by Yi et al. (2004) with the addition that phosphatidylcholine may be present.

\section{Description of Serinicoccus profundi sp. nov.}

Serinicoccus profundi (pro'fun.di. L. gen. n. profundi of/ from the depths of the sea).

Gram-reaction-positive, moderately halophilic and aerobic. Oxidase-negative and catalase-positive. No spore formation. Cells are non-motile cocci. Growth occurs with 0 $14 \%(\mathrm{w} / \mathrm{v}) \mathrm{NaCl}$ (optimum 3-5\%), at $\mathrm{pH}$ 6-11 (optimum $\mathrm{pH} 7$ ) and at $10-35{ }^{\circ} \mathrm{C}$ (optimum $30{ }^{\circ} \mathrm{C}$ ). Colonies on ZBA are yellow, circular, convex, entire, glistening, opaque
Table 1. Characteristics that differentiate strain MCCC $1 \mathrm{~A} 05965^{\top}$ from its closest phylogenetic neighbour

Data were obtained in this study.

\begin{tabular}{|c|c|c|}
\hline Characteristic & $\begin{array}{c}\text { MCCC } \\
1 \mathrm{~A} 05965^{\mathrm{T}}\end{array}$ & $\begin{array}{c}\text { S. marinus } \\
\text { DSM } 15273^{\mathrm{T}}\end{array}$ \\
\hline Phosphatidylcholine & + & - \\
\hline Alkaline phosphatase & + & - \\
\hline \multicolumn{3}{|l|}{ Utilization of (Biolog GP2): } \\
\hline Cellobiose & - & + \\
\hline$\beta$-Cyclodextrin & - & + \\
\hline D-Arabitol & - & + \\
\hline D-Mannitol & - & + \\
\hline D-Psicose & - & + \\
\hline Trehalose & + & - \\
\hline$\alpha$-Ketovaleric acid & + & - \\
\hline Pyruvic acid methyl ester & + & - \\
\hline \multicolumn{3}{|l|}{ Resistance to $(\mu \mathrm{g})$ : } \\
\hline Ampicillin (10) & + & - \\
\hline Carbenicillin (100) & + & - \\
\hline Cefalexin (30) & + & - \\
\hline Cefazolin (30) & + & - \\
\hline Cefuroxime (30) & + & - \\
\hline Cephalothin (30) & + & - \\
\hline Cephradin (30) & + & - \\
\hline Lincomycin (2) & + & - \\
\hline Oxacillin (1) & + & - \\
\hline Penicillin G (10) & + & - \\
\hline Piperacillin (100) & + & - \\
\hline
\end{tabular}

and butyraceous after 2 days at $28{ }^{\circ} \mathrm{C}$. Does not produce $\mathrm{H}_{2} \mathrm{~S}$ on triple-sugar iron agar. DNA and Tween 80 are decomposed. With API 20NE, positive for nitrate reduction, aesculin hydrolysis, gelatin decomposition, $p$-nitrophenyl- $\beta$-D-galactopyranosidase and utilization of D-glucose, maltose, D-mannose, potassium gluconate and malic acid but negative for indole production, acid production from glucose, arginine dihydrolase, urease and utilization of L-arabinose, D-mannitol, $\mathrm{N}$-acetylglucosamine, adipic acid, capric acid, trisodium citrate and phenylacetic acid. With API ZYM, positive for alkaline phosphatase, esterase lipase (C8), leucine arylamidase, valine arylamidase and $\alpha$-glucosidase; variable for esterase (C4), trypsin, $\alpha$-chymotrypsin, cystine arylamidase and $\beta$ glucosidase; negative for lipase (C14), acid phosphatase, naphthol-AS-BI-phosphohydrolase, $\alpha$-fucosidase, $\alpha$-galactosidase, $\beta$-galactosidase, $\beta$-glucuronidase, $N$-acetyl- $\beta$-glucosaminidase and $\alpha$-mannosidase. With the Biolog GP2 MicroPlate, positive for oxidation of dextrin, glycogen, D-gluconic acid, $\alpha$-D-glucose, maltose, maltotriose, D-mannose, raffinose, D-ribose, stachyose, sucrose, trehalose, $\alpha$-hydroxybutyric acid, $\alpha$-ketovaleric acid, L-lactic acid, pyruvic acid methyl ester, pyruvic acid, L-alaninamide, glycerol, adenosine, inosine, thymidine, uridine, adenosine $5^{\prime}$-monophosphate, thymidine $5^{\prime}$-monophosphate and uridine $5^{\prime}$-monophosphate; weakly positive for oxidation of Tweens 40 and 80, L-arabinose, D-fructose, methyl 
$\alpha$-D-glucoside, palatinose, D-sorbitol, turanose, $\beta$-hydroxybutyric acid, $\gamma$-hydroxybutyric acid, $\alpha$-ketoglutaric acid, D-lactic acid methyl ester, L-malic acid, succinic acid monomethyl ester, succinic acid, 2,3-butanediol and 2'deoxyadenosine. Sensitive to ( $\mu$ g per disc unless otherwise indicated) bacitracin $(0.04 \mathrm{U})$, chloromycetin (30), ciprofloxacin (5), erythromycin (15), minomycin (30), norfloxacin (10), novobiocin (30), rifampicin (5) and tetracycline (30). Resistant to ampicillin (10), carbenicillin (100), cefalexin (30), cefazolin (30), cefuroxime (30), cephalothin (30), cephradin (30), lincomycin (2), oxacillin (1), penicillin G (10) and piperacillin (100). The polar lipids are phosphatidylglycerol, diphosphatidylglycerol, phosphatidylinositol, phosphatidylcholine and an unknown glycolipid. The major fatty acids are iso- $\mathrm{C}_{15: 0}$, iso- $\mathrm{C}_{16: 0}$, anteiso- $\mathrm{C}_{15: 0}$, iso- $\mathrm{C}_{17: 0}$ and anteiso- $\mathrm{C}_{17: 0}$. The major menaquinone is MK- $8\left(\mathrm{H}_{4}\right)$. The DNA $\mathrm{G}+\mathrm{C}$ content of the type strain is $72 \mathrm{~mol} \%$.

The type strain, MCCC $1 \mathrm{~A} 05965^{\mathrm{T}}\left(=0714 \mathrm{S6}-1^{\mathrm{T}}=\mathrm{DSM}\right.$ $21363^{\mathrm{T}}=$ CGMCC $4.5582^{\mathrm{T}}$ ), was isolated from a deep-sea sediment.

\section{Acknowledgements}

J. Xu is indebted to the National Science Foundation of China (grant no. 40606031), the National High Technology R\&D Program of China (grant no. 2007AA091904) and the China Ocean Mineral Resources Research and Development Association (grant no. DYXM115-02-2-8).

\section{References}

Altschul, S. F., Madden, T. L., Schaffer, A. A., Zhang, J., Zhang, Z., Miller, W. \& Lipman, D. J. (1997). Gapped BLAST and PSI-BLAST: a new generation of protein database search programs. Nucleic Acids Res 25, 3389-3402.

Chun, J. \& Goodfellow, M. (1995). A phylogenetic analysis of the genus Nocardia with 16S rRNA gene sequences. Int J Syst Bacteriol 45, 240-245.

Chun, J., Lee, J. H., Jung, Y., Kim, M., Kim, S., Kim, B. K. \& Lim, Y. W. (2007). EzTaxon: a web-based tool for the identification of prokaryotes based on $16 \mathrm{~S}$ ribosomal RNA gene sequences. Int J Syst Evol Microbiol 57, 2259-2261.

Collins, M. D., Pirouz, T., Goodfellow, M. \& Minnikin, D. E. (1977). Distribution of menaquinones in actinomycetes and corynebacteria. J Gen Microbiol 100, 221-230.

Czerny, G. (1978). Studies on aminopeptidase for the distinction of Gram-negative from Gram-positive bacteria. Eur J Appl Microbiol Biotechnol 5, 113-122.

Felsenstein, J. (1985). Confidence limits on phylogenies: an approach using the bootstrap. Evolution 39, 783-791.
Gontang, E. A., Fenical, W. \& Jensen, P. R. (2007). Phylogenetic diversity of gram-positive bacteria cultured from marine sediments. Appl Environ Microbiol 73, 3272-3282.

Komagata, K. \& Suzuki, K. (1987). Lipid and cell-wall analysis in bacterial systematics. Methods Microbiol 19, 161-207.

Kroppenstedt, R. M. (1985). Fatty acid and menaquinone analysis of actinomycetes and related organisms. In Chemical Methods in Bacterial Systematics (Society for Applied Bacteriology Technical Series vol. 20), pp. 173-199. Edited by M. Goodfellow \& D. E. Minnikin. New York: Academic Press.

Kumar, S., Tamura, K. \& Nei, M. (2004). MEGA3: integrated software for molecular evolutionary genetics analysis and sequence alignment. Brief Bioinform 5, 150-163.

MacKenzie, S. L. (1987). Gas chromatographic analysis of amino acids as the $N$-heptafluorobutyryl isobutyl esters. J Assoc Off Anal Chem 70, 151-160.

Mesbah, M., Premachandran, U. \& Whitman, W. B. (1989). Precise measurement of the $\mathrm{G}+\mathrm{C}$ content of deoxyribonucleic acid by highperformance liquid chromatography. Int J Syst Bacteriol 39, 159167.

Saitou, N. \& Nei, M. (1987). The neighbor-joining method: a new method for reconstructing phylogenetic trees. Mol Biol Evol 4, 406425.

Sasser, M. (1990). Identification of bacteria by gas chromatography of cellular fatty acids. USFCC Newsl 20, 16.

Schleifer, K. H. (1985). Analysis of the chemical composition and primary structure of murein. Methods Microbiol 18, 123-156.

Schleifer, K. H. \& Kandler, O. (1972). Peptidoglycan types of bacterial cell walls and their taxonomic implications. Bacteriol Rev 36, 407477.

Shirling, E. B. \& Gottlieb, D. (1966). Methods for characterization of Streptomyces species. Int J Syst Bacteriol 16, 313-340.

Tamaoka, J. \& Komagata, K. (1984). Determination of DNA base composition by reversed-phase high-performance liquid chromatography. FEMS Microbiol Lett 25, 125-128.

Thompson, J. D., Gibson, T. J., Plewniak, F., Jeanmougin, F. \& Higgins, D. G. (1997). The CLUSTAL_X windows interface: flexible strategies for multiple sequence alignment aided by quality analysis tools. Nucleic Acids Res 25, 4876-4882.

Uchida, K., Kudo, T., Suzuki, K. \& Nakase, T. (1999). A new rapid method of glycolate test by diethyl ether extraction, which is applicable to a small amount of bacterial cells of less than one milligram. J Gen Appl Microbiol 45, 49-56.

Weisburg, W. G., Barns, S. M., Pelletier, D. A. \& Lane, D. J. (1991). 16S ribosomal DNA amplification for phylogenetic study. J Bacteriol 173, 697-703.

Xu, J., Wang, Y., Xie, S. J., Xu, J., Xiao, J. \& Ruan, J. S. (2009). Streptomyces xiamenensis sp. nov., isolated from mangrove sediment. Int J Syst Evol Microbiol 59, 472-476.

Yi, H., Schumann, P., Sohn, K. \& Chun, J. (2004). Serinicoccus marinus gen. nov., sp. nov., a novel actinomycete with L-ornithine and L-serine in the peptidoglycan. Int J Syst Evol Microbiol 54, 1585-1589. 